
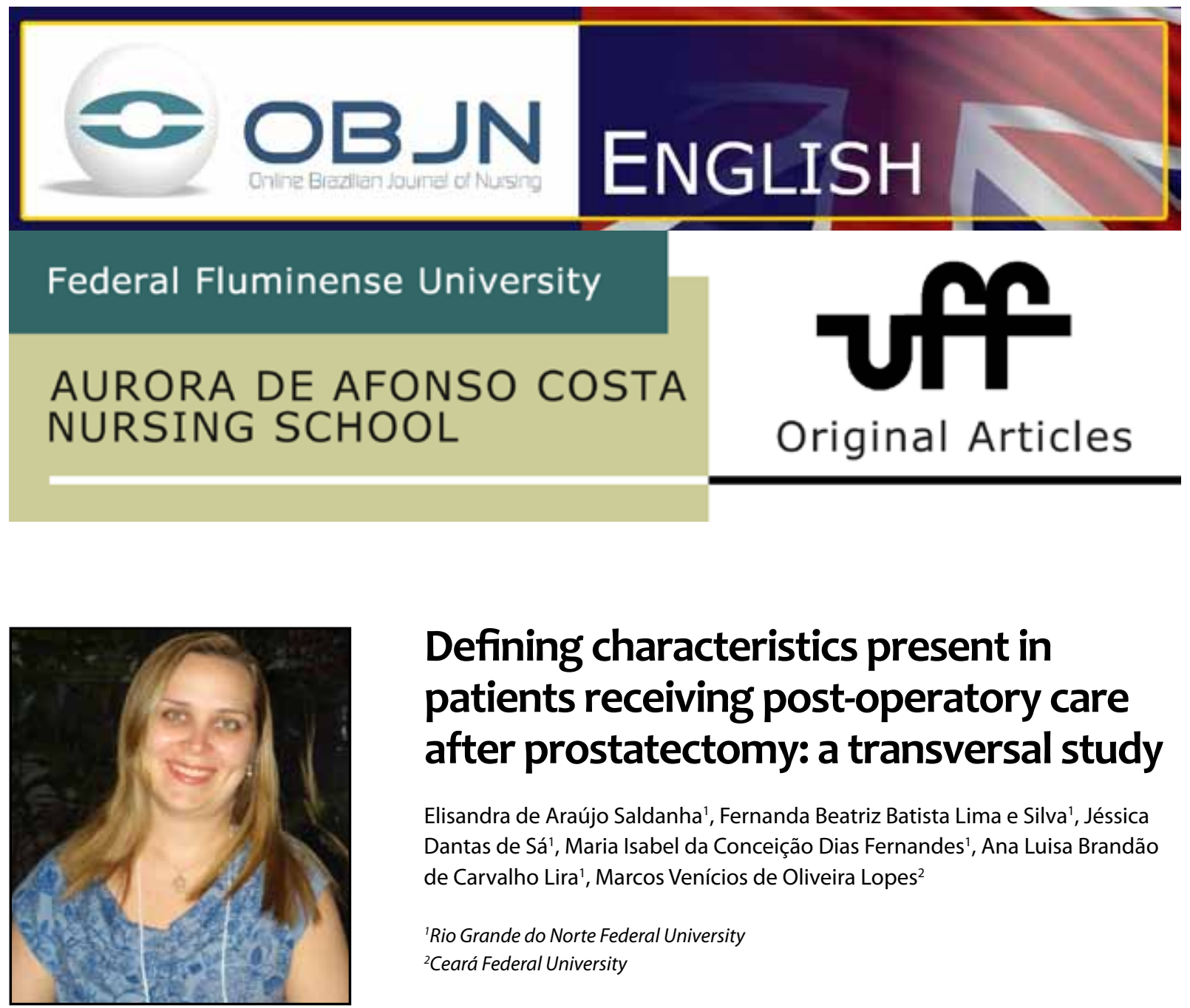

\title{
Defining characteristics present in patients receiving post-operatory care after prostatectomy: a transversal study
}

\begin{abstract}
Elisandra de Araújo Saldanha', Fernanda Beatriz Batista Lima e Silva', Jéssica Dantas de Sá', Maria Isabel da Conceição Dias Fernandes', Ana Luisa Brandão de Carvalho Lira' ${ }^{1}$, Marcos Venícios de Oliveira Lopes ${ }^{2}$
\end{abstract}

'Rio Grande do Norte Federal University

${ }^{2}$ Ceará Federal University

\section{ABSTRACT}

Aim: To identify the defining characteristics in patients receiving immediate post-operatory care after prostatectomy.

Method: This is a quantitative, transversal and descriptive study performed on 50 patients during the immediate post-operatory care after prostatectomy in a College hospital of a city located in the northeast region of Brazil.

Results: 50 defining characteristics were found related especially to the physiological and security needs of the patient, such as problems regarding ambulation, self-care, pain, sight, hearing, sleeping, understanding and intestinal patterns. Of the total, 15 characteristics were present in all patients.

Discussion: The defining characteristics found in all patients were linked to ambulation and self-care. These elements emphasize the limitations of the patients to perform daily tasks independently.

Conclusion: The defining characteristics found are important hints to help nursing diagnoses. Based on priority diagnosis, it is possible to plan and implement systematized nursing assistance.

Descriptors: Signs and Symptoms; Nursing Diagnosis; Prostatectomy; Postoperative Period. 


\section{INTRODUCTION}

Prostatectomy is a treatment usually performed in patients with benign hyperplasia or cancer of the prostate. This surgical procedure can generate complications to the patient during the period of immediate post-operatory care (up to 48 hours after the surgery). These include hemorrhage, infection, formation of a clot that obstructs the catheter, and deep vein thrombosis ${ }^{(1)}$. The late post-operatory care on the other hand focuses on problems different from those previously mentioned, for example sexual dysfunction and urinary incontinence, which can compromise quality of life and cause constraint, loss of self-esteem and social isolation ${ }^{(2,3)}$.

In regards to the immediate post-operatory care, the nurse must develop strategies to avoid the aforementioned health complications. This can be by avoiding or interrupting bleeding through the administration of drugs, venous liquids or hemoderivatives according to prescription, as well as paying attention to register the hydric balance; to use aseptic technique in all procedures and while administrating antibiotics when an infection is found; to apply compressive socks; and to proceed with therapies using thrombolysis whenever prescribed ${ }^{(1)}$.

As well as the caring provided during hospitalization it is also the role of the nurse to prepare the patient to be discharged through explanations regarding home care, which involve the maintenance of the drainage system, the monitoring of urinary debt and the care of the operatory wound ${ }^{(1)}$. Therefore, nurses must plan to focus on the necessities of the individual, aiming to provide a wide, individualized and systematized caring service.

For such, this professional must use a Nursing Process (NP), which is considered a differentiated instrument, accessible and useful to organize a nurse's work ${ }^{(4)}$. NP is divided into five stages: nursing records/physical exam, nursing diagnosis, planning, prescription of nursing care, and evaluation ${ }^{(5)}$.

With the use of NP it is possible to provide a more qualified caring service, observing that this assistance is guided and registered based on the results obtained from the interventions carried out. Moreover, it also contributes to professional visibility and recognition ${ }^{(4)}$.

Therefore, the nurse needs to know the stages of NP and work with the standardized systems of the elements described in professional practice in order to promote a systematized caring service and the recovery of the patient.

Of the stages of NP we highlight the second, nursing diagnosis, which was created to subsidize a universal language that describes nursing understanding and practice, and aimed to inform nursing interventions and results ${ }^{(6)}$.

Nursing diagnoses are clinical evaluations performed by the nurse based on the health problems presented by the individual/family/ community. From the identification of these diagnoses, the nurse draws the necessary interventions to achieve the expected results. Such diagnoses are based on clinical logic and the evaluation of the set of defining characteristics seen in the patient. These characteristics are considered true hints (or signs and symptoms) that help the nurse to decide the correct nursing diagnosis. Furthermore, they are identified through clinical analysis, which means from both anamnesis and the physical exam carried out by the nurse ${ }^{(7)}$.

The defining characteristics are important to identify for the diagnosis as they are observable indicators in an individual, grouped as manifestations of a diagnosis ${ }^{(8)}$. These characteristics can provide relevant suggestions to ensure the absence or presence of a certain diagnosis ${ }^{(9)}$.

From research on defining characteristics it is possible to trace the profile of the main 
problems presented by a patient after prostatectomy. As a consequence, it helps the nurse to plan the caring service given to these patients and guarantees a quality nursing caring service.

With this perspective this study looked to identify the defining characteristics seen in patients in the immediate post-operatory care period after a prostatectomy, aiming to improve nursing by focusing on the real needs of the patient.

\section{METHOD}

This is a transversal study, with a quantitative approach. Transversal studies are characterized by an analysis of the existing relationship between diseases or other characteristics related to the health of the individual and how they appear in a certain population in a specific moment ${ }^{(10)}$. Quantitative studies give accuracy, impartiality and an ability to replicate data using statistical resources and techniques ${ }^{(11)}$.

This research was done in a surgical clinic, and more specifically in a urology nurse ward of a college hospital located in a city in northeastern Brazil. The study contained 102 patients who underwent prostatectomy from 2009 to 2010, according to the computer system of the aforementioned hospital. The sample was calculated based on a formula developed for studies with finite populations, from which it was decided to have a sample of 50 men:

$\mathrm{n}=\left(\mathrm{Z}_{\mathrm{a}}{ }^{*} \mathrm{P} * \mathrm{Q}{ }^{*} \mathrm{~N}\right) /\left(\mathrm{Z}_{a}{ }^{2 *} \mathrm{P} * \mathrm{Q}\right)+(\mathrm{N}-1){ }^{*} \mathrm{E}^{2}$

where:

$\mathrm{n}=$ size of the sample;

$z_{\alpha}=95 \%$ (coefficient of confidence);

$\mathrm{N}=102$ (size of the population);

$E=10 \%$ (absolute sample error);

$\mathrm{Q}=$ complementary percentage $(100-\mathrm{P})$;

$P=50 \%$ (proportion of occurrence of a studied phenomenon) $)^{(12)}$.
The criteria of inclusion adopted were: to have medical diagnosis of benign prostatic hyperplasia or a prostatic neoplasm; to have received prostate surgery during the research; and to be found in immediate post-operatory care (up to 48 hours after the surgery) during the collection of data. The exclusion criteria were: to not be in suitable physical and mental conditions to participate in the research; prostatectomy patient with cardiac, pulmonary, hepatic, encephalic vascular, coronary or extensive peripheral illnesses.

To collect the information we used an interview guide and physical exam. The data was collected between November 2010 and April 2011 after a patient's signature on the free and clear consent agreement from.

The data acquired was organized in an electronic worksheet and analyzed through an individual process of clinical logic and judgment of defining characteristics present in prostatectomy patients. This process ended with the design of a table with all identified defining characteristics and their respective relative and absolute frequencies. The data was discussed with reference to the literature related to the topic.

The research was approved by the Ethics Committee of Rio Grande do Norte Federal University, under protocol number 130/10 and accredited by the Certificate of Presentation for Ethical Appreciation registry number 0147.0.051.000-10.

\section{RESULTS}

Concerning the characteristics of the investigated patients, the majority was composed of elders (88\%), with an average age of 67.78 years old, retired (60\%) and a family income of up to four minimum wages (94\%). With regard to personal 
circumstances, $80 \%$ had a partner, had up to four children (56\%), were Roman Catholics (78\%), and residents from cities from the inner state (90\%). Based on their education, $44 \%$ were illiterate and $40 \%$ did not finish elementary school.

Among the patients, a total of 50 defining characteristics were identified during the period of immediate post-operatory care. In Table 1 the identified defining characteristics found in 100\% of the patients are presented.

Table 1 - Distribution of the observed definying characteristics of patients in immediate postoperatory care of prostatectomy in a College Hospital. Natal, 2010-2011

\begin{tabular}{|c|c|c|}
\hline Signs and symptoms & $\mathbf{n}$ & $\%$ \\
\hline Impaired capacity to walk uphill & 50 & 100 \\
\hline Impaired capacity to walk downhill & 50 & 100 \\
\hline $\begin{array}{l}\text { Impaired capacity to walk neeeded } \\
\text { distances }\end{array}$ & 50 & 100 \\
\hline $\begin{array}{l}\text { Impared capacity to walk in irregular } \\
\text { surfaces }\end{array}$ & 50 & 100 \\
\hline Incapacity to access restrooms & 50 & 100 \\
\hline Incapacity to wash the body & 50 & 100 \\
\hline Incapacity to dry the body & 50 & 100 \\
\hline Incapacity to reach the toilet seat & 50 & 100 \\
\hline $\begin{array}{l}\text { Incapacity to perform appropriate intima- } \\
\text { te hygiene }\end{array}$ & 50 & 100 \\
\hline $\begin{array}{l}\text { Incapacity to handle clothing to perform } \\
\text { intimate hygiene }\end{array}$ & 50 & 100 \\
\hline $\begin{array}{l}\text { Impared capacity to wear necessary } \\
\text { clothes }\end{array}$ & 50 & 100 \\
\hline $\begin{array}{l}\text { Incapacity to wear clothes on the lower } \\
\text { body }\end{array}$ & 50 & 100 \\
\hline $\begin{array}{l}\text { Incapacity to wear clothes on the upper } \\
\text { body }\end{array}$ & 50 & 100 \\
\hline Incapacity to reach clothes & 50 & 100 \\
\hline Incapacity to take off clothes & 50 & 100 \\
\hline
\end{tabular}

Source: Self-elaborated, based in Herdman (2013).

According to Table 1 we identified a total of 15 defining characteristics in the patients receiving prostate surgery, which were related especially to deficits in self-care and harmed ambulation.

In Table 2, 35 defining characteristics that were not present in all patients of the sample are presented. However, they are seen as real problems faced by these patients and are linked to pain, disturbed visual and auditory sensory perception, insomnia, disturbed sleeping patterns, a deficient in understanding, and constipation.

Table 2 - Distribution of the low incidence characteristics in patients in immediate postoperative care due to prostatectomy in a College Hospital. Natal, Brazil, 2010-2011.

\begin{tabular}{|c|c|c|}
\hline Signs and symptoms & $\mathbf{n}$ & $\%$ \\
\hline Oral report of pain & 18 & 36 \\
\hline Observed evidence of pain & 16 & 32 \\
\hline Change of sensorial acuity & 15 & 30 \\
\hline Pacient reports difficulty to stay asleep & 13 & 26 \\
\hline Behavior of protection & 10 & 20 \\
\hline Verbalizarion of the problem & 10 & 20 \\
\hline Change of usual response to stimulus visual & 10 & 20 \\
\hline Reports of difficulty to sleep & 8 & 16 \\
\hline Reports of difficulty to stay awake & 7 & 14 \\
\hline Sleep disorder & 7 & 14 \\
\hline $\begin{array}{l}\text { Change of usual response to stimulus } \\
\text { auditory }\end{array}$ & 7 & 14 \\
\hline Hard and shaped feces & 6 & 12 \\
\hline Changes in blood presure & 5 & 10 \\
\hline Changes in heart frequency & 5 & 10 \\
\hline Changes in the frequency of breath & 5 & 10 \\
\hline Sensorial distortions & 5 & 10 \\
\hline Observed lack of energy & 5 & 10 \\
\hline Change of the normal pattern of sleeping & 5 & 10 \\
\hline Patient reports unsatisfactory sleeping & 4 & 8 \\
\hline Distended abdomen & 4 & 8 \\
\hline Exagerated behavior & 4 & 8 \\
\hline Difficulty to evacuate & 3 & 6 \\
\hline Inadequate instruction follow up & 3 & 6 \\
\hline Patient reports non-restorative sleep & 3 & 6 \\
\hline Impaired communication & 3 & 6 \\
\hline Pain while evacuating & 2 & 4 \\
\hline Hypoactive intestinal noise & 1 & 2 \\
\hline Reduced frequency in evacuation & 1 & 2 \\
\hline Anorexia & 1 & 2 \\
\hline Vomits & 1 & 2 \\
\hline Incapacity to eliminate feces & 1 & 2 \\
\hline Reduced volume of feces & 1 & 2 \\
\hline Change in appetitis & 1 & 2 \\
\hline Facial expression & 1 & 2 \\
\hline Position to avoid pain & 1 & 2 \\
\hline
\end{tabular}

Source: Self-generated, based in Herdman (2013). 


\section{DISCUSSION}

The defining characteristics found in 100\% of the patients are explained by the fact that the majority were elders with poor peripheral venous access, continuous catheter irrigation and being hospitalized in wards equipped with an excessive number of pieces of furniture, low lightning and bathrooms without non-slip surfaces.

The defining characteristics found in 100\% of the individuals in this study can be categorized into the following nursing diagnoses of NANDA International ${ }^{(8)}$ : "Harmed ambulation"; "Deficits in self-care to shower"; "Deficits in self-care for intimate hygiene"; and "Deficits in self-care to get dressed".

Harmed ambulation in patients during the immediate post-operatory care of a prostatectomy can be directly linked to the pain and to the lowered mental state. The hospital environment is also considered to be an aggravating factor to harmed ambulation as it can present environmental limitations, such as irregular surfaces, stairs and obstacles in general, amongst others. The deficits in self-care to shower and in intimate hygiene and dressing are directly linked to the presence of obstacles in the environment and pain and discomfort. These last two originated from the surgical procedure ${ }^{(13)}$.

Furthermore, patients in immediate post-operatory care of a prostatectomy usually use many hospital instruments, such as serum support, venous access, indwelling urinary catheter, urine collection bag and drains. These combine with the surgical incision and complicates ambulation and the performance of self-care. Patients therefore demand support in daily routine activities.

The requirement for support in their daily lives, as required by the prostatectomy patient, refers back to the stereotype created by society that men must be strong, both physically and emotionally. As a consequence, the idea of self-sufficiency for men impedes the acceptance of care that is provided in the moment that the patient is in a dependent state ${ }^{(14)}$.

The defining characteristics are: verbal report of pain (36\%); observed evidence of pain (32\%); protective behavior (20\%); sleep disturbance (14\%); alteration in blood pressure (10\%); changes in cardiac frequency (10\%); changes in respiratory frequency (10\%); changes in appetite (2\%); facial expression (2\%); and position to avoid pain (2\%). These show the variety of clinical indications of the diagnosis of "pain" present in prostatectomy patients.

Pain is a common diagnosis in immediate post-operatory care patients ${ }^{(15)}$. After a prostatectomy this sensation can be related to the surgical incision, the place of insertion of the urinary catheter, and to urinary spasms. The irritability of the bladder can cause bleeding. This can develop into a clot, leading to urinary retention that can also cause pain ${ }^{(1)}$.

The defining characteristics of "changes in visual sensory acuity" (30\%), "changes in usual response to visual stimulus" (20\%) and "visual sensory distortions" (10\%) are related to changes in vision. The defining characteristics of "changes in auditory sensory acuity" (28\%), "changes in usual responses to auditory stimulus" (14\%), "auditory sensorial distortions" (10\%) and "harmed communication" (6\%) are related to changes in hearing. All these clinical traces show a relationship with the diagnoses called "Visual disturbed sensorial perception" and "Auditory disturbed sensorial perception".

Considering that the sample was mainly composed of elders (88\%), the signs of sensorial loss are justified. It is known that with aging there are sensorial losses that affect the sensorial organs. Usually, after fifty years old the crystalline is less flexible and therefore the maximum 
point of focus is more distant from the eye. This causes presbyopia: reading glasses are necessary to focus the objects ${ }^{(1)}$.

As with vision, when people age there is a gradual loss of hearing. Exposure to environmental noise contributes significantly to hearing loss, which is seen especially in the elderly ${ }^{(1)}$. Therefore, we observe the important role of nursing in protecting elder patients in the period of immediate post-operatory care with alterations in auditory and visual sensory perception.

The defining characteristics of "patient reports difficulty to stay asleep" (26\%), "patient reports difficulty to fall asleep" (24\%), "lack of energy observed" (10\%), "patient reports sleep dissatisfaction" (8\%) and "patient reports non-restorative sleep" (6\%) are declared in the nursing diagnosis of "Insomnia". Insomnia is a symptom presented by patients who have some disturbance in the quantity and quality of sleep so as to impede the normal functioning of the body ${ }^{(8)}$. The presence of this diagnosis can be associated with a fear of pain, death, changes in body structure and function or changes in lifestyle ${ }^{(1)}$.

In these patients it was also seen that the problems related to sleep were linked to interruptions in their sleep during the nighttime, which directly affects the quality and quantity of sleep. Therefore, the defining characteristics of "reports of difficulty to fall asleep" (24\%), "reports to stay awake" (14\%), "changes in the normal patterns of sleep" (10\%) and "patient reports dissatisfactory sleep" (8\%) were gathered in the diagnosis of "Harmed sleeping pattern", which is related to the interruption of sleep due to external factors ${ }^{(8)}$.

The occurrence of the abovementioned diagnosis has a strong relationship with the fact that the sample studied is mostly formed by elders. Some studies show that $65 \%$ of elders between 65 and 84 years old present some problems related to sleep. Such problems are also identified in $22 \%$ to $61 \%$ of hospitalized patients. In this scenario we would like to draw attention to the hospital environment as a source of sleep deprivation due to excessive noise and lightning ${ }^{(16)}$.

Therefore, the nurse must evaluate the factors that are contributing to sleep deprivation in order to fight them, or at least to minimize them in order to promote a better quality sleep for the patient. The nurse must utilize measures to improve sleep in order to assist the patient to fall and stay asleep, while reducing the quantity of medication used to aid sleep. With this perspective and with nursing interventions to ameliorate the situation, we suggest relaxation through massage and music, a reduction in body temperature with a shower, and a reduction of noise, light and the interruptions of sleep during the night $^{(16)}$.

It is valid to mention that the defining characteristics inserted in the nursing diagnoses "Insomnia" and "Harmed sleep pattern" are similar, but differ in definition and meaning, and therefore are set as distinctive defining characteristics. Besides this, such diagnoses have distinctive definitions, despite the fact they are both related to sleeping: "Insomnia" is a difficulty in falling asleep while "Harmed sleep pattern" is linked mainly to interruptions while sleeping.

The defining characteristics of "verbalization of the problem" (20\%), "excessive behavior" (8\%), "inadequate instruction follow up" (6\%) and "improper behavior" (4\%) lead to a "Deficit of understanding". In a study about prostatectomy, patients found this last diagnosis in $100 \%$ of the studied sample ${ }^{(17)}$.

It is understood that patients receiving prostatectomy surgery usually have many doubts and expectancies, both with regard to the procedure itself and the results from the intervention ${ }^{(18)}$. Therefore, it is important that 
the nurse is focused to ensure that patients understand the effects and promote the inclusion of relatives in the treatment. Furthermore, nurses must teach self-care procedures, which must be carefully planned. For such tasks, professionals should use individualized approaches ${ }^{(17)}$.

Research about the expectations of the patient regarding prostate surgery and the post-operatory period revealed that patients in general do not know about the problems that come from the surgical procedure and the moments after the incision. This affirmation was based on discourse collected from patients, who reported that they were sure that they would be completely healed by the procedure and would return to their normal routine as before they had the confirmation of the diagnosis ${ }^{(19)}$. This demonstrated a deficit in understanding regarding the possible complications in the immediate and late post-operatory periods. Consequently, nursing should communicate in an accessible language to the patient and relatives in order to properly explain the care needed, clearing all existing doubts.

The defining characteristics of "hard and formed feces" (12\%), "distended abdomen" (8\%), "effort to evacuate" (6\%), "pain while evacuating" (4\%), "hypoactive intestinal noises" (2\%), "reduced frequency to evacuate" (2\%), "anorexia" (2\%), "vomit" (2\%), "incapacity to eliminate feces" (2\%) and "reduced volume of feces" (2\%) pointed to the presence of "Constipation".

These characteristics are common in patients in post-operatory care due to prolonged fasting, which is worsened by the reduction of physical activity as a result of the reduction in gastrointestinal motility. Furthermore, there is also stress, anxiety, use of drugs that interfere with peristalsis, interrupted intestinal routine, dehydration, and changes in the environment that can all influence the patient's intestinal pattern ${ }^{(20)}$.
With nursing interventions against constipation, the patient must be informed regarding the importance of having a diet rich in fiber and increasing the ingestion of liquids, as well as being stimulated to ambulate and practice exercises that work with abdominal muscles, for example sit-ups four times a day ${ }^{(1)}$.

\section{CONCLUSION}

We identified 50 defining characteristics in the patients of this study. These characteristics were related to problems in ambulation, self-care, pain, vision, hearing, sleep, understanding and intestinal patterns. Among them, 15 characteristics were present in all patients and were related to ambulation and self-care. This draws attention to the limitation of these patients to be independent in their daily lives.

The identified defining characteristics in the patients of this study compose the clinical evidence of nursing diagnoses more frequently presented by individuals in the immediate post-operatory care period after a prostatectomy. Through the clinic logic and the evaluation of the defining characteristics, these were identified as the main responses in this particular population due to the demographics of the population.

Moreover, the defining characteristics reflect the clinical traces of nursing diagnoses of each patient. Through observation it is possible to develop nursing planning with the implementation and evaluation of successful conduct being adopted. Therefore, the nurse has an important role to clearly identify these characteristics from the first contact with the patient until the final evaluation.

Additionally, the nurse should consider the difficulty a man has to look for medical assistance and accept the recommendations from this service. This comes from a historical background 
related to the male gender, where men feel that they must be strong, both physically and emotionally, and not let themselves show signs of dependency during moments of illness. Thus, during professional practice, the nurse must consider the role of gender and plan more appropriately to implement caring services. From the start, NP is an important tool in caring as it helps to organize nursing work and enables the patient to receive holistic assistance.

We expect that this study can contribute to the scientific background that informs the practice of nursing professionals who watch over patients undergoing a prostatectomy in a way that the professionals are motivated to use NP on a routine basis, and this procedure can help generate new studies involving this topic.

As a limitation of this study, we would like to mention the short period of time of immediate post-operatory care in which we interviewed the patients as during this period the participants were drowsy and no very collaborative, which sometimes interfered with the interviews.

\section{REFERENCES}

1. Smeltzer SC, Bare BG, Hinkle JL, Cheever KH. Brunner \& Suddarth's textbook of medical surgicalnursing. 12. ed. Philadelphia: Lippincott Willians \&Wilkins; 2012.

2. Liatsikos EN, Assimakopoulos K, Stolzenburg J. Quality of life after radical prostatectomy. Urol int. 2008; 80 (3):226-30.

3. Zavala, MW, Maliski SL, Kwan L, Miller DC, Fink A, Litwin MS. Longitudinal quality of life in low-income men in a state-funded prostate cancer treatment program. J Health Care Poor Underserved [Internet]. 2008 [cited 2013 June 22]; 19:200-15. Available from: http://link.periodicos. capes.gov.br.ez18.periodicos.capes.gov.br.

4. Garcia T, Nóbrega MML. Processo de enfermagem: da teoria à prática assistencial e de pesquisa.
Esc Anna Nery Rev Enferm [Internet]. 2009 [cited 2013 July 14]; 13(1):816-18. Available from: http:// www.scielo.br/scielo.php?script=sci_arttext\&pi $\mathrm{d}=\mathrm{S} 141481452009000100026 \& \mathrm{ng}=\mathrm{en}$. http:// dx.doi.org/10.1590/S1414-81452009000100026.

5. Salomão GSM, Azevedo RCS. Evaluate the bibliographic production on nursing process in Brazil. Acta Paul Enferm. 2009; 22(5):691-5.

6. Herdman TH. What nursing knowledge is needed to develop nursing practice? Rev eletrônica enferm [Internet]. 2011 [cited 2013 july 16];13(2):159-60. Available from: http://www.fen. ufg.br/revista/v13/n2/v13n2a01-en.

7. Aliti GB, Linhares JCC, Linch GFC, Ruschel KB, Rabelo ER. Sinais e sintomas de pacientes com insuficiência cardíaca descompensada: inferência dos diagnósticos de enfermagem prioritários. Rev gaúcha enferm. 2011; 32 (3):590-5.

8. Herdman TH. Diagnósticos de Enfermagem da NANDA: definições e classificação - 2012/2014. 2. ed. Porto Alegre: Artmed; 2013.

9. Matos FGOA, Cruz DALM. Construção de instrumento para avaliar a acurácia diagnóstica. Rev Esc Enferm USP. 2009; 43:1088-97.

10. Lima D. Research design: a contribution to the author. Online braz j nurs [the Internet]. Oct 2011 [Cited 2013 July 14] 10(2): [about 5 p.]. Available from: http://www.objnursing.uff.br/index.php/ nursing/article/view/3648. doi: http://dx.doi. org/10.5935/1676-4285.20113648

11. Polit DF, Beck CT. Essentials of Nursing Research: Appraising Evidence for Nursing Practice. 7. ed. Philadelphia: Lippincott Willians \& Wilkins; 2011.

12. Arango HG. Bioestatística teórica e computacional. Rio de Janeiro: Grupo Editorial Nacional Participações S/A (GEN); 2009.

13. Saldanha EA. Diagnósticos de enfermagem em pacientes no pós-operatório imediato de prostatectomia de um hospital universitário de Natal-RN. [Dissertação de mestrado]. Natal: Universidade Federal do Rio Grande do Norte; 2011.

14. Pinheiro TF, Couto MT, Silva GSN. Homens e cuidado: Construções de masculinidades na saúde pública brasileira. Psicología, Conocimiento y Sociedad [internet]. 2012[cited 2013 June 22]; 2(2):177-95. Available from: http://revista.psico. edu.uy/index.php/revpsicologia/article/download/142/78. 
15. Mineiro FHGR. Avaliação da dor pós-operatória: análise em pacientes submetidos a cirurgias abdominais em um hospital universitário de Natal/RN. [Dissertação de mestrado]. Natal: Universidade Federal do Rio Grande do Norte; 2010.

16. Lareau R, Benson L, Watcharotone K, Manguba G. Examining the feasibility of implementing specific nursing interventions to promote sleep in hospitalized elderly patients. Geriatr Nurs. 2008; 29(3):197-206.

17. Napoleão AA, Caldato VG, Filho JFP. Diagnósticos de enfermagem para o planejamento da alta de homens prostatectomizados: um estudo preliminar. Rev eletrônica enferm [Internet]. 2009 [cited 2012 Oct 15]; 11(2):286-94. Available from: http:// www.fen.ufg.br/revista/v11/n2/v11n2a08.htm.

18. Vianna MC, Napoleão AA. Reflexões sobre cuidados de enfermagem para a alta de pacientes prostatectomizados. Ciênc cuid saúde. 2009; 8(2):269-73.

19. Madeira MZA, Alves RC, Reis RLM, Silva Júnior FJG, Santos AMR. A expectativa do paciente no pré e pós-operatório de prostatectomia. Revista interdisciplinar NOVAFAPI. 2010; 3(1):1-7.

20. Torres $A C$, Diccini S. Constipação intestinal em pacientes com tumores intracranianos. Rev Latinoam enferm. 2006; 14 (3):397-404.
Received: $10 / 10 / 2012$

Revised: 24/06/2013

Approved: $14 / 07 / 2013$

Participation of the authors in the research

Elisandra de Araújo Saldanha: Conceived the study, reviewed literature, designed tables, interpreted data.

Fernanda Beatriz Batista Lima e Silva: Conceived the study, reviewed literature, collected data, wrote the text, designed tables, interpreted data.

Jéssica Dantas de Sá: Conceived the study, collected data, wrote the text, designed tables, interpreted data.

Maria Isabel da Conceição Dias Fernandes: Conceived the study, reviewed literature, wrote the text, designed tables, interpreted data.

Ana Luisa Brandão de Carvalho Lira: Conceived and delimited the study, interpreted data, performed critical review of the article, final approval of the article.

Marcos Venícios de Oliveira Lopes: Conceived and delimited the study, statistically analyzed the data, performed critical review of the article, final approval of the article. 